\title{
Characterization of the root system of the Conilon coffee plant under localized irrigation
}

\author{
Caracterización del sistema radicular Conilon café bajo riego por goteo \\ Joabe Martins de Souza1*, Edvaldo Fialho dos Reis ${ }^{2}$, Robson Bonomo ${ }^{3}$, \\ Giovanni de Oliveira Garcia' ${ }^{2}$ Lucas Rosa Pereira²
}

\begin{abstract}
Coffee is a crop of great economic importance in Brazil. To ensure high productivity, and profitability irrigation management becomes important. The knowledge of the crop's root system is of utmost importance for the development of the crop as for the correct management of irrigation. The objective of this study was to characterize the root system of the Conilon coffee plant under localized irrigation. The experiment was carried out in two cultivated areas in São Mateus-ES, in a completely randomized design in a plot subdivided $4 \times 6$, four points concerning the plant and six depths, with five replications. There were two in the line and six in line with a distance between them $0.20 \mathrm{~m}$. The line between the coffee portion is divided into $6 \times 5$, five points concerning the plantation, and the depth of six tracks, with five repetitions. Volume, surface area, length, and root diameter were evaluated. The coffee Conilon under drip under (area 01 ) showed $74.5 \%$ and $64.5 \%$ (sandy to medium texture), and $75.4 \%$ and $70.2 \%$ (sandy to clay texture) of the volume and root surface area, concentrated up to the depth of $0.30 \mathrm{~m}$. The root system of the Conilon genotype 02 presented $70.5 \%$ of the root volume for both textures studied, up to $0,60 \mathrm{~m}$ of the plant's trunk. The root surface area was $69 \%$ and $66.4 \%$ up to $0.60 \mathrm{~m}$ of the plant's trunk for areas 01 and 02 , respectively.
\end{abstract}

Keywords: Coffea canephora, root volume, root surface area, root length, drip.

\section{RESUMEN}

El café es un cultivo de gran importancia económica en Brasil. Para asegurar una alta productividad y rentabilidad se vuelve importante el manejo del riego. El conocimiento del sistema radicular del cultivo es de suma importancia para el desarrollo del cultivo como para el correcto manejo del riego. El objetivo de este estudio fue caracterizar el sistema radicular de la planta de café Conilon bajo riego localizado. El experimento se llevó a cabo en dos áreas cultivadas en São Mateus-ES, en un diseño completamente al azar en una parcela subdividida: $4 \times 6$, cuatro puntos con respecto a la planta y seis profundidades, con cinco repeticiones. Siendo dos en línea y seis entre línea con una distancia entre ellas de 0,20 m; $6 x$, cinco puntos en referencia a la plantación y seis bandas de profundidad, con cinco repeticiones. Se evaluó el volumen, área superficial, longitud y diámetro de raíz. El café Conilon bajo goteo (área 01) mostró 74,5\% y 64,5\% (en textura arenosa a media), y 75,4\% y 70,2\% (en textura arenosa a arcillosa) del volumen y área de la superficie radicular, concentrada hasta la profundidad de 0,30 m. Em el sistema de raíces del genotipo Conilon 2, el 70,5\% presento un volumen de raíz para ambas texturas estudiadas a 0,60 $\mathrm{m}$ del tallo de la planta. El área superficial de raíz fue de 69\% y 66,4\% hasta 0,60 m del tronco del árbol para las áreas 01 y 02 , respectivamente.

Palabras clave: Coffea canéfora, volumen de raíz, área superficial de raíz, longitud de raíz, goteo.

\section{Introduction}

The Conilon (Coffea canephora Pierre ex Froenher) is the most planted coffee species in the state of Espírito Santo, with average productivity of 19.3 sacks benefiting from $60 \mathrm{~kg} \mathrm{ha}^{-1}$. The state production of 5, 03 million bags in 2016 accounted for $63.0 \%$ of the Brazilian coffee Conilon (Conab, 2017).

The Conilon coffee cultivation has been carried out mostly under irrigation, $\mathrm{d}$ between the irrigation systems commonly employed in coffee-growing in this region, the localized systems (drip irrigation, conventional, microjet dripping, and micro-sprinkler),

\footnotetext{
Universidade Federal do Espírito Santo/UFES. São Mateus, ES, Brasil.

2 Universidade Federal do Espírito Santo/UFES, Departamento de Engenharia Rural. Alegre, ES, Brasil.

3 Universidade Federal do Espírito Santo/UFES, Departamento de Ciências Agrárias e Biológicas. São Mateus, ES, Brasil.

* Corresponding author: HYPERLINK “mailto:joabenv@gmail.com”joabenv@gmail.com
} 
and spray (central pivot, fixed and conventional spraying) (Bonomo et al., 2014).

Although there are reports in the literature that the greater robustness of Conilon coffee is associated with the greater extension and efficiency of its root system, both in water and nutrient uptake, the distribution, architecture, and depth of the roots can be affected by several such as water regime, type of irrigation, planting density, localization of fertilizers, genotypes, among others (Rena and DaMatta, 2002).

According to Amaral et al. (2011) and Martins et al. (2015), factors such as root growth, mycorrhizae, root morphology, absorption mechanisms, and the volume of soil explored by the roots can lead to differences in nutrient absorption efficiency between soil cultivars and, consequently, different nutritional efficiencies of plants.

It is important to point out that irrigation affects root allocation, distribution, and root growth, depending on plant growth strategies and its overall response to deficits and distribution of available water in the soil (Belan et al., 2011; Comas et al., 2013).

In order to determine the best irrigation system (Barreto et al., 2006), the knowledge of the root system can be used to estimate the need for coffee water (Silva et al., 2009). One important aspect for irrigation management is the depth of the root system, which interferes with the water depth to be applied to the crop since an incorrect estimation of the depth of the root system may lead to a deficit or excess of the leaf value. irrigation. Due to this importance, it is necessary to determine and analyze its distribution in irrigated crops.

In view of the above, the objective was to characterize the root system of coffee Conilon under localized irrigation.

\section{Materials and Methods}

The experiment was conducted in two areas of coffee Conilon (Coffea canephora Pierre ex Froehner), "Conilon Vitória" cultivar, irrigated by drip irrigation. The areas are located in the municipality of São Mateus, ES, at an altitude of 39 meters. Clone 02 , one of the most productive and planted clones in the region, was used to evaluate the experiment. The soils of study areas 01 and 02 were classified as Red Yellow Latosol, sandy to medium texture, and Red Yellow Latosol with sandy to clay texture, typical of trays according to the methodology of Embrapa (2013), predominating in all areas with flat topography with a slope of less than $1 \%$.

The textural characterization and physical-hydric soils were carried out according to the methodology of the Embrapa (2011), which disturbed and undisturbed samples were taken in two positions, in line, and between the planting line in four depths ranges (from 0.00 to $0,20,0.20-0.40,0.40-0.60$ and $0.60-0.80 \mathrm{~m}$ ), in four replicates, according to Table 1 and 2.

Table 1. Mean values sand, silt and clay in four tracks depths and two positions in the two areas cultivated with coffee Conilon, in São Mateus-ES.

\begin{tabular}{|c|c|c|c|c|c|}
\hline \multirow{2}{*}{ Areas } & \multirow{2}{*}{ Positions } & \multirow{2}{*}{ Depths (m) } & Sand & Clay & Silt \\
\hline & & & \multicolumn{3}{|c|}{$\mathrm{g} \mathrm{Kg}^{-1}$} \\
\hline \multirow{8}{*}{1} & \multirow{4}{*}{ Line } & $0.00-0.20$ & 730.01 & 265.93 & 4.06 \\
\hline & & $0.20-0.40$ & 730.92 & 264.65 & 4.43 \\
\hline & & $0.40-0.60$ & 675.11 & 319.86 & 5.03 \\
\hline & & $0.60-0.80$ & 663.57 & 331.45 & 4.98 \\
\hline & \multirow{4}{*}{ Between } & $0.00-0.20$ & 728.05 & 266.30 & 5.65 \\
\hline & & $0.20-0.40$ & 727.77 & 267.12 & 5.11 \\
\hline & & $0.40-0.60$ & 671.87 & 322.17 & 5.96 \\
\hline & & $0.60-0.80$ & 664.02 & 330.96 & 5.02 \\
\hline \multirow{8}{*}{2} & \multirow{4}{*}{ Line } & $0.00-0.20$ & 698.20 & 297.65 & 4.15 \\
\hline & & $0.20-0.40$ & 704.20 & 290.02 & 5.78 \\
\hline & & $0.40-0.60$ & 674.33 & 320.87 & 4.80 \\
\hline & & $0.60-0.80$ & 653.93 & 340.34 & 5.73 \\
\hline & \multirow{4}{*}{ Between } & $0.00-0.20$ & 680.75 & 313.24 & 6.01 \\
\hline & & $0.20-0.40$ & 690.34 & 303.77 & 5.89 \\
\hline & & $0.40-0.60$ & 670.97 & 323.38 & 5.65 \\
\hline & & $0.60-0.80$ & 652.02 & 343.09 & 4.89 \\
\hline
\end{tabular}


Table 2. Physical-water attributes of the soils in four depth ranges and two positions in in the two areas cultivated with coffee Conilon, in São Mateus-ES.

\begin{tabular}{|c|c|c|c|c|c|c|c|}
\hline \multirow{2}{*}{ Areas } & \multirow{2}{*}{ Positions } & \multirow{2}{*}{ Depth (m) } & \multirow{2}{*}{ Ds $\left(\mathrm{g} \mathrm{cm}^{-3}\right)$} & Macro & Micro & $\mathrm{CC}$ & PMP \\
\hline & & & & \multicolumn{4}{|c|}{$(\%)$} \\
\hline \multirow{8}{*}{1} & \multirow{4}{*}{ Line } & $0.00-0.20$ & 1.49 & 26.31 & 18.45 & 19.8 & 8.5 \\
\hline & & $0.20-0.40$ & 1.56 & 26.07 & 18.89 & 19.5 & 8.6 \\
\hline & & $0.40-0.60$ & 1.64 & 18.65 & 21.56 & 18.8 & 8.1 \\
\hline & & $0.60-0.80$ & 1.66 & 17.44 & 22.68 & 18.9 & 8.7 \\
\hline & \multirow{4}{*}{ Between } & $0.00-0.20$ & 1.63 & 19.45 & 21.89 & 19.5 & 8.6 \\
\hline & & $0.20-0.40$ & 1.62 & 18.78 & 21.78 & 19.3 & 8.7 \\
\hline & & $0.40-0.60$ & 1.65 & 18.90 & 22.04 & 18.4 & 8.9 \\
\hline & & $0.60-0.80$ & 1.68 & 19.02 & 22.10 & 18.2 & 8.9 \\
\hline \multirow{8}{*}{2} & \multirow{4}{*}{ Line } & $0.00-0.20$ & 1.55 & 23.56 & 18.98 & 22.6 & 8.5 \\
\hline & & $0.20-0.40$ & 1.58 & 23.80 & 18.64 & 22.3 & 8.0 \\
\hline & & $0.40-0.60$ & 1.66 & 17.76 & 21.78 & 21.6 & 8.0 \\
\hline & & $0.60-0.80$ & 1.68 & 17.56 & 22.89 & 21.6 & 7.9 \\
\hline & \multirow{4}{*}{ Between } & $0.00-0.20$ & 1.60 & 20.80 & 16.50 & 22.2 & 8.4 \\
\hline & & $0.20-0.40$ & 1.61 & 19.57 & 18.89 & 22.1 & 8.1 \\
\hline & & $0.40-0.60$ & 1.68 & 17.89 & 21.32 & 21.4 & 7.9 \\
\hline & & $0.60-0.80$ & 1.68 & 17.67 & 22.59 & 21.2 & 7.9 \\
\hline
\end{tabular}

In what: Ds - Soil density; Macro - Macroporosity; Micro - Microporosity; CC - Field Capacity (\% vol); PMP - Permanent Murcha Point (\% vol).

The areas were pruned using the programmed cycle pruning technique in the years 2015 (area 01) and 2016 (area 02). Areas 01 and 02 constituted clone 02 of the "Conilon Vitória" cultivar, with 6 and 5 years of age respectively, with spacing 3 $\mathrm{x} 0.8 \mathrm{~m}$. The irrigation system used in both areas was located by drip irrigation, with emitters spaced $0.50 \mathrm{~m}$ apart.

Irrigation management was carried out using two hours of irrigation every day, with emitter flow of $2.5 \mathrm{~L} \mathrm{~h}^{-1}$, with Christiansen - CUC uniformity and distribution coefficient - CUD equal to 90 and $89 \%$, and 91 and $90 \%$ for area 01 and 02 , respectively.

The root system of the coffee was evaluated in a completely randomized design in two split plot scheme $4 \times 6$, four points with respect to the plant $(0.20$ and 0.40 on the line and in between 0.20 and 0.40 line of the coffee tree) and six depth (0.00-0.10, 0.10-0.20, $0.20-0.30,0.30-0.40,0.40-0.50$ and $0.50-0.60 \mathrm{~m}$ ), and another $5 \times 6$, being five points in relation to the plant in between $(0.60,0.80,1.0,1.2,1.4 \mathrm{~m})$ and six depth bands $(0.00-0.10,0.10-0.20,0.20-0.30,0.30-0.40$, $0.40-0.50$ and $0.50-0.60 \mathrm{~m}$ ), both with five replicates.

For the characterization of the root system of the coffee plants, soil samples with roots in the two experimental areas were collected with a probe of
$283 \mathrm{~cm}^{3}$, identified and stored in plastic bags, and kept in a freezer (approximately $-10{ }^{\circ} \mathrm{C}$ ) until the washing for separating the roots that were held under running water at 30 sieve mesh, then transferred to another 60 mesh and again washed in running water.

The roots were digitized in a scanner; from the obtained images, it is possible to determine the volume, surface area, length, and diameter of roots, through the software program for the analysis of fibers and roots, 1.1 (Jorge et al., 2010). For analysis, roots smaller than $1 \mathrm{~mm}$ in diameter were used, and the data were estimated by $\mathrm{dm}^{3}$ of soil.

The data were submitted to analysis of variance and compared by the Scott- Knott test in 5\% of probability, comparing the points between plant and up to $0,40 \mathrm{~m}$ in between line, and another comparison of 0.60 to $1.4 \mathrm{~m}$ in line.

\section{Results and discussion}

For area 01, the points near the plant, the largest root volume was found in the depth range $0.00-0.10 \mathrm{~m}$, being statistically equal to the depth of $0.20-0.30 \mathrm{~m}$ to $0.40 \mathrm{~m}$ distant from the plant in line, and 0,40 in the line, and to 0,40;0.60 and $1 \mathrm{~m}$ in the row (Table 3). Similar results were found 
Table 3. Characteristics of the root system of the irrigated Conilon coffee tree cultivated in a Yellow Red Latosol, sandy the average texture, in two distances of the plant in the line (L) and two in the between, and at five distances on the between, in six depths.

\begin{tabular}{|c|c|c|c|c|c|c|}
\hline \multirow{3}{*}{$\begin{array}{l}\text { Distances of } \\
\text { the plant }(\mathrm{m})\end{array}$} & \multicolumn{6}{|c|}{ Depths (m) } \\
\hline & $0.00-0.10$ & $0.10-0.20$ & $0.20-0.30$ & $0.30-0.40$ & $0.40-0.50$ & $0.50-0.60$ \\
\hline & \multicolumn{6}{|c|}{ Volume $\left(\mathrm{mm}^{3}\right)$} \\
\hline $0.40 \mathrm{~L}$ & $2356.23 \mathrm{bA}$ & $2356.23 \mathrm{bA}$ & $2356.23 \mathrm{bA}$ & $2356.23 \mathrm{bA}$ & $2356.23 \mathrm{bA}$ & $2356.23 \mathrm{bA}$ \\
\hline $0.20 \mathrm{~L}$ & $845.70 \mathrm{cB}$ & $845.70 \mathrm{cB}$ & $845.70 \mathrm{cB}$ & $845.70 \mathrm{cB}$ & $845.70 \mathrm{cB}$ & $845.70 \mathrm{cB}$ \\
\hline 0.20 & $2519.90 \mathrm{aA}$ & $2519.90 \mathrm{aA}$ & $2519.90 \mathrm{aA}$ & $2519.90 \mathrm{aA}$ & $2519.90 \mathrm{aA}$ & $2519.90 \mathrm{aA}$ \\
\hline \multirow[t]{2}{*}{0.40} & $865.78 \mathrm{aB}$ & $865.78 \mathrm{aB}$ & $865.78 \mathrm{aB}$ & $865.78 \mathrm{aB}$ & $865.78 \mathrm{aB}$ & $865.78 \mathrm{aB}$ \\
\hline & \multicolumn{6}{|c|}{ Surface area $\left(\mathrm{cm}^{2} \mathrm{dm}^{-3}\right)$} \\
\hline $0.40 \mathrm{~L}$ & $228.15 \mathrm{bA}$ & $122.31 \mathrm{bB}$ & $222.72 \mathrm{bA}$ & $108.59 \mathrm{bC}$ & $44.70 \mathrm{cD}$ & $23.10 \mathrm{dE}$ \\
\hline $0.20 \mathrm{~L}$ & $92.72 \mathrm{cC}$ & $164.62 \mathrm{aB}$ & $191.69 \mathrm{cA}$ & $82.34 \mathrm{cC}$ & $86.81 \mathrm{bC}$ & $42.12 \mathrm{cD}$ \\
\hline 0.20 & $316.76 \mathrm{aA}$ & $172.71 \mathrm{aC}$ & $239.29 \mathrm{aB}$ & $55.68 \mathrm{dE}$ & $44.16 \mathrm{cE}$ & $94.01 \mathrm{bD}$ \\
\hline \multirow[t]{2}{*}{0.40} & $224.30 \mathrm{bA}$ & $89.33 \mathrm{cD}$ & $60.43 \mathrm{dE}$ & $155.32 \mathrm{aB}$ & $122.49 \mathrm{aC}$ & $153.27 \mathrm{aB}$ \\
\hline & \multicolumn{6}{|c|}{ Length $\left(\mathrm{m} \mathrm{dm}^{-3}\right)$} \\
\hline $0.40 \mathrm{~L}$ & $39.68 \mathrm{aA}$ & $12.18 \mathrm{cB}$ & $11.64 \mathrm{bB}$ & $8.70 \mathrm{aC}$ & $5.03 \mathrm{bD}$ & $8.62 \mathrm{bC}$ \\
\hline $0.20 \mathrm{~L}$ & $16.15 \mathrm{~dB}$ & $23.41 \mathrm{aA}$ & $11.14 \mathrm{bC}$ & $9.23 \mathrm{aC}$ & $5.33 \mathrm{bD}$ & $2.64 \mathrm{dE}$ \\
\hline 0.20 & $34.84 \mathrm{bA}$ & $18.31 \mathrm{bC}$ & $22.09 \mathrm{aB}$ & $7.26 \mathrm{aD}$ & $4.58 \mathrm{bD}$ & $6.24 \mathrm{cD}$ \\
\hline \multirow[t]{2}{*}{0.40} & $26.65 \mathrm{cA}$ & $8.98 \mathrm{dD}$ & $8.97 \mathrm{bD}$ & $9.39 \mathrm{aD}$ & $15.79 \mathrm{aB}$ & $12.15 \mathrm{aC}$ \\
\hline & \multicolumn{6}{|c|}{ Diameter (mm) } \\
\hline $0.40 \mathrm{~L}$ & $0.642 \mathrm{aB}$ & $0.650 \mathrm{aB}$ & $0.636 \mathrm{aB}$ & $0.636 \mathrm{bB}$ & $0.696 \mathrm{aA}$ & $0.652 \mathrm{aB}$ \\
\hline $0.20 \mathrm{~L}$ & $0.622 \mathrm{aB}$ & $0.632 \mathrm{aB}$ & $0.628 \mathrm{aB}$ & $0.624 \mathrm{bB}$ & $0.668 \mathrm{bA}$ & $0.668 \mathrm{aA}$ \\
\hline 0.20 & $0.624 \mathrm{aB}$ & $0.622 \mathrm{aB}$ & $0.652 \mathrm{aB}$ & $0.684 \mathrm{aA}$ & $0.696 \mathrm{aA}$ & $0.642 \mathrm{aB}$ \\
\hline \multirow[t]{2}{*}{0.40} & $0.618 \mathrm{aB}$ & $0.632 \mathrm{aB}$ & $0.626 \mathrm{aB}$ & $0.656 \mathrm{aA}$ & $0.650 \mathrm{bA}$ & $0.652 \mathrm{aA}$ \\
\hline & \multicolumn{6}{|c|}{ Volume $\left(\mathrm{mm}^{3}\right)$} \\
\hline 0.60 & $818.69 \mathrm{cA}$ & $344.19 \mathrm{dD}$ & $639.30 \mathrm{bA}$ & $453.99 \mathrm{bC}$ & $334.40 \mathrm{aB}$ & $373.65 \mathrm{cD}$ \\
\hline 0.80 & $1168.36 \mathrm{bA}$ & $528.81 \mathrm{cB}$ & $287.68 \mathrm{dC}$ & $269.59 \mathrm{dC}$ & $339.31 \mathrm{aC}$ & $556.85 \mathrm{bB}$ \\
\hline 1.0 & $1455.04 \mathrm{aA}$ & $1337.97 \mathrm{aB}$ & $1442.08 \mathrm{aA}$ & $855.81 \mathrm{aC}$ & $343.05 \mathrm{aE}$ & $755.95 \mathrm{aD}$ \\
\hline 1.2 & $837.87 \mathrm{cA}$ & 846.89 bA & $281.54 \mathrm{~dB}$ & $342.69 \mathrm{cB}$ & $252.89 \mathrm{bC}$ & $337.22 \mathrm{cB}$ \\
\hline \multirow[t]{2}{*}{1.4} & $1430.39 \mathrm{aA}$ & $545.87 \mathrm{cB}$ & $428.34 \mathrm{cB}$ & $341.60 \mathrm{cD}$ & $251.46 \mathrm{bE}$ & $138.16 \mathrm{dF}$ \\
\hline & \multicolumn{6}{|c|}{ Surface area $\left(\mathrm{cm}^{2} \mathrm{dm}^{-3}\right)$} \\
\hline 0.60 & $120.54 \mathrm{cA}$ & $120.54 \mathrm{cA}$ & $120.54 \mathrm{aA}$ & $120.54 \mathrm{cA}$ & $120.54 \mathrm{cA}$ & $120.54 \mathrm{cA}$ \\
\hline 0.80 & $96.13 \mathrm{bB}$ & $96.13 \mathrm{bB}$ & $96.13 \mathrm{bB}$ & $96.13 \mathrm{bB}$ & $96.13 \mathrm{bB}$ & $96.13 \mathrm{bB}$ \\
\hline 1.0 & $85.64 \mathrm{cC}$ & $85.64 \mathrm{cC}$ & $85.64 \mathrm{cC}$ & $85.64 \mathrm{cC}$ & $85.64 \mathrm{cC}$ & $85.64 \mathrm{cC}$ \\
\hline 1.2 & $96.02 \mathrm{bB}$ & $96.02 \mathrm{bB}$ & $96.02 \mathrm{bB}$ & $96.02 \mathrm{bB}$ & $96.02 \mathrm{bB}$ & $96.02 \mathrm{bB}$ \\
\hline \multirow[t]{2}{*}{1.4} & $51.34 \mathrm{bD}$ & $51.34 \mathrm{bD}$ & $51.34 \mathrm{bD}$ & $51.34 \mathrm{bD}$ & $51.34 \mathrm{bD}$ & $51.34 \mathrm{bD}$ \\
\hline & \multicolumn{6}{|c|}{ Length $\left(\mathrm{m} \mathrm{dm}^{-3}\right)$} \\
\hline 0.60 & $12.80 \mathrm{bA}$ & $6.37 \mathrm{bC}$ & $8.55 \mathrm{bB}$ & $9.59 \mathrm{bB}$ & $5.64 \mathrm{aC}$ & $8.64 \mathrm{aB}$ \\
\hline 0.80 & $10.65 \mathrm{cA}$ & $2.37 \mathrm{cC}$ & $1.28 \mathrm{dC}$ & $1.27 \mathrm{dC}$ & $1.24 \mathrm{cC}$ & $8.89 \mathrm{aB}$ \\
\hline 1.0 & $6.79 \mathrm{~dB}$ & $5.70 \mathrm{bB}$ & $12.20 \mathrm{aA}$ & $11.70 \mathrm{aA}$ & $2.79 \mathrm{bC}$ & $5.98 \mathrm{bB}$ \\
\hline 1.2 & $17.54 \mathrm{aA}$ & $16.41 \mathrm{aA}$ & $4.16 \mathrm{cC}$ & $4.33 \mathrm{cC}$ & $5.48 \mathrm{aC}$ & $8.54 \mathrm{aB}$ \\
\hline \multirow[t]{2}{*}{1.4} & $18.97 \mathrm{aA}$ & $6.12 \mathrm{bC}$ & $8.39 \mathrm{bB}$ & $4.94 \mathrm{cC}$ & $5.20 \mathrm{aC}$ & $6.26 \mathrm{bC}$ \\
\hline & \multicolumn{6}{|c|}{ Diameter (mm) } \\
\hline 0.60 & $0.670 \mathrm{aA}$ & $0.672 \mathrm{aA}$ & $0.656 \mathrm{aA}$ & $0.656 \mathrm{bA}$ & $0.662 \mathrm{aA}$ & $0.648 \mathrm{bA}$ \\
\hline 0.80 & $0.658 \mathrm{aB}$ & $0.636 \mathrm{bB}$ & $0.646 \mathrm{aB}$ & $0.646 \mathrm{bB}$ & $0.674 \mathrm{aA}$ & $0.698 \mathrm{aA}$ \\
\hline 1.0 & $0.660 \mathrm{aA}$ & $0.668 \mathrm{aA}$ & $0.664 \mathrm{aA}$ & $0.670 \mathrm{aA}$ & $0.654 \mathrm{aA}$ & $0.684 \mathrm{aA}$ \\
\hline 1.2 & $0.650 \mathrm{aA}$ & $0.654 \mathrm{bA}$ & $0.638 \mathrm{aA}$ & $0.652 \mathrm{bA}$ & $0.668 \mathrm{aA}$ & $0.660 \mathrm{bA}$ \\
\hline 1.4 & $0.630 \mathrm{aB}$ & $0.688 \mathrm{aA}$ & $0.658 \mathrm{aA}$ & $0.670 \mathrm{aA}$ & $0.676 \mathrm{aA}$ & $0.640 \mathrm{bB}$ \\
\hline
\end{tabular}

The averages followed by the same lowercase letter in the column and uppercase in the row do not differ statistically from one another. The Scott- Knott Test was applied at a 5\% probability level. 
by Partelli et al. (2006), which observed a higher concentration of roots in the upper depth range $(0.00-0.10 \mathrm{~m})$, followed by the posterior bands in the order of depth, both at $0,25 \mathrm{~m}$ and $0,50 \mathrm{~m}$ plant.

When the distances concerning the plant were analyzed, the most prominent root volume close to the plant was found at $0.20 \mathrm{~m}$ in the coffee line, which differed from the other distances up to the depth of 0.10-0.20 m, where higher root volume was also found at $0.20 \mathrm{~m}$ in the row, the same result was found for the depth of 0.00-0.10 m.

The result that shows higher root volume in the superficial part of the soil, as verified by Mota et al. (2006), who reported the highest concentration of coffee roots up to $0.20 \mathrm{~m}$ depth, and Rodrigues et al. (2001), who observed lower concentrations of roots in deeper soil layers. It is important to highlight that in the depth range $0.20-0.30 \mathrm{~m}$ to $0.40 \mathrm{~m}$ away from the plant in the line and between the lines, they presented the highest volumes of roots, statistically equal to each other.

When analyzing the coffee line, it is observed that, numerically, the root volume is smaller concerning the points near the plant, with the largest volumes observed in the depth range 0.00-0.10 m, being statistically equal to the range of depth 0.20 $0.30 \mathrm{~m}$ for the 0.60 and $1.0 \mathrm{~m}$ points of the plant, with a significant reduction from the depth range for all distant plant points in the line.

The largest root surface area was found $0.20 \mathrm{~m}$ away from the plant in the inter-row at depths 0.00 $0.10 ; 0.10-0.20$, and $0.20-0.30 \mathrm{~m}$, differing statistically from the other distances, except in the depth of 0.10$0.20 \mathrm{~m}$, which was statistically equal to the distance of $0.20 \mathrm{~m}$ of the plant in the planting line (Table 3). A similar result was found by Partelli et al. (2014), who found the largest root surface areas up to the $0.30 \mathrm{~m}$ layer but did not verify the interaction between plant distance and soil depth, which may be related to the number of points sampled.

Despite a larger surface area in the three depths previously mentioned, in the depth of 0.00-0.10 m, a larger surface area differing from the other depths at 0.20 and $0.40 \mathrm{~m}$ distant from the plant in the line (Table 3) was observed. For the points in the coffee line, the greatest surface area was found in the depth of 0.20-0.30 m, differing from the others at 0.20 and $0.40 \mathrm{~m}$ distance from the plant, the latter being statistically equal to the depth of $0.00-0.10 \mathrm{~m}$.

The results show a larger surface area near the plant and in the initial depths of the soil, being of great importance for nutrient and water absorption, as reported by Imada et al. (2008), who stated that the root surface area is that it is more related to the absorption of nutrients. Greater surface area can help the plant to obtain nutrients from different sources, favoring the exploration and obtaining of water and nutrients

In the coffee line, the largest surface areas were found in the $0.00-0.10 \mathrm{~m}$ depth range, for points $0.60 ; 0.80$; and $1.4 \mathrm{~m}$ distant from the plant, already to the distant point $1.2 \mathrm{~m}$ greater surface area was found in the depth range of $0.10-0.20 \mathrm{~m}$. In the depth range of $0.20-0.30 \mathrm{~m}$, the highest values were found at a $1.0 \mathrm{~m}$ distance from the plant. These important results show a root development of coffee plants capable of using water and nutrients farther from the plant.

The root length was concentrated in the soil surface at $3 \mathrm{~mm}$ application, but when the distances of the plant were analyzed, a different behavior was observed, with a considerable root length near the plant, observing the greater lengths in the depth of $0.00-0.10 ; 0.10-0.20$ and $0.20-0.30 \mathrm{~m}$, at the points 0.20 and $0.40 \mathrm{~m}$ in the line and $0.20 \mathrm{~m}$ in the coffee line, respectively, which differed from the other points regarding the plant studied (Table 3 ).

Already Partelli et al. (2006), when evaluating the length and surface area of the root system, verified a statistical difference between the profiles sampled at 0.25 and $0.50 \mathrm{~m}$ of the trunk of the coffee tree. However, these differences occurred only in the depth range of 0,40-0,60 m.

When the coffee line was analyzed, it observed the same behavior of the points close to the plant with greater length in the soil surface depth range, with longer lengths found at 1,2 and 1,4 m distant from the plant, being these statistically the same, Already in the depth range $0.20-0.30 \mathrm{~m}$ the largest length was found at $1 \mathrm{~m}$ of the plant.

The root diameter had a smaller diameter of the depth range of 0.00-0.10 to $0.30-0.40 \mathrm{~m}$, being statistically equal, in the distant points 0,20 and $0,40 \mathrm{~m}$ in the line, already for the distances 0.20 and 0.40 in the line, this result was observed up to the depth range of $0.20-0.30 \mathrm{~m}$ (Table 3 ). These results show that in addition to becoming thinner, in this area studied and in the bands of initial depths of the soil, they promote an increase in the surface area of the root system as observed in Table 3 and mentioned by Marschner (2011).

For depth to $0.20-0.30 \mathrm{~m}$, the points were statistically the same, with the smallest diameters, 
and in depths beyond these distances, a smaller diameter was observed at 0.20 and $0.40 \mathrm{~m}$ (line). In the line, the smallest diameter was observed at $0,80 \mathrm{~m}$ distant from the plant, being also that at that point until the depth range $0,30-0,40 \mathrm{~m}$ presented the smallest diameters.

The results reported so far show that for the coffee tree, the root system distributed more on the soil surface, showing that for this area, there is a need for adequate irrigation management, related to the necessary real irrigation, which is inserted in the calculation depth of the root system, which directly influences the irrigation blade to be applied.

In area 02 , the lower root volumes were observed since this crop was conducted with only one stem (orthropic branch), that is, with a minor aerial part than the previous area (Table 4). There is a relationship between the area and the root system, as reported by Partelli et al. (2006), that several factors can influence the development and distribution of the root system, among them the frequency of aerial and root pruning. The highest root volume was found to be $0.10-0.20 \mathrm{~m}, 0.60 \mathrm{~m}$ from the plant, with the significant volume also being between the distances to the plant in this depth range, differing from the others (Table 4).

For the other distances, the largest volumes were found in the depth range of $0.00-0.10 \mathrm{~m}$, a fact observed when the coffee line did not differ, with the largest volume found at $0.20 \mathrm{~m}$ distant from the plant on the other line of the coffee tree (Table 4). The results were similar to those found by Ronchi et al. (2015) in Arabica coffee, where they observed a greater abundance of roots in the $0,10 \mathrm{~m}$ depth layer compared to the $0,40 \mathrm{~m}$ layer.

The root surface area obtained values close to area 01 ; for this crop, the largest root surface area was observed at a distance of $0.40 \mathrm{~m}$ in the coffee line in the depth range of 0.00-0.10 m, differing of the other depths and distance from the plant (Table 4). The same behavior was observed in the distances of 0.60 and $0.80 \mathrm{~m}$ of the plant, in the depth range of $0.00-0.10 \mathrm{~m}$.

As for the distance of $0.20 \mathrm{~m}$ in the coffee line to the depth of $0.00-0.10 \mathrm{~m}$, it was statistically equal to the depth range of $0.20-0.30 \mathrm{~m}$, and for this latter depth was observed the largest surface area for this point, differing from the others. For the depth range $0.10-0.20 \mathrm{~m}$, a greater surface area was found at $0.40 \mathrm{~m}$ in the coffee line, which differed from the other points and depths studied (Table 4).
According to Ronchi et al. (2015) studied Arabica coffee, verified that the root system is more abundant and presents superior morphological attributes when sampled between two adjacent plants in the planting line, followed by the positions separated at $0,25 \mathrm{~m}$ and $0,50 \mathrm{~m}$ from the trunk, with a dependent response spacing.

The root length showed similar behavior to area 01 , being vaster in the depth range of $0.00-0.10 \mathrm{~m}$, except for the distant points 0.20 and $0.40 \mathrm{~m}$ of the plant in the coffee line, which presented higher root length in the 0.10-0.20 m depth range (Table 4). For this depth range, the greatest distance between distances was found to be $0.20 \mathrm{~m}$ away from the plant in the planting line, differing from the other points. This morphophysiological attribute shows the potential of coffee to absorb water and nutrients (Cassidy and Kumar, 1984; Rena and Guimarães, 2000; Rena and DaMatta, 2002) and in adapt to different spatial arrangements.

For the depths of 0.00-0.10 and 0.20-0.30 m, the largest length was found in the distance of $0.20 \mathrm{~m}$ in the line, being that for depth of $0.20-0.30$, the distant point $0.40 \mathrm{~m}$, was statistically equal to $0.20 \mathrm{~m}$ of the plant.

According to Silva et al. (2013), the efficiency of nutrient uptake by plants can be improved by the selection of cultivars with more extended root surface and roots with thin roots, show the importance of this root characteristic also for a correct management of irrigation, to provide greater efficiency in the use of irrigation water.

It was also observed a smaller diameter in the $0.00-0.10 \mathrm{~m}$ depth range at $0.40 \mathrm{~m}$ (line), which was statistically equal to the depth range of $0.20-0.30 \mathrm{~m}$, already towards the point $0.20 \mathrm{~m}$ (row), the largest diameter was in the depth bands of 0.00-0.10 and 0.10-0.20 m, which differed from the others (Table 4).

In this same distance in the line, a smaller diameter in the depths 0.00-0.10 and 0,30-0,40 m, being statistically equal. For the points close to the plant ( $0.20 \mathrm{~m}$ (line), 0.20 and $0.40 \mathrm{~m}$ (between) presented the smallest diameters at depths of 0.100.20 and $0.20-0.30 \mathrm{~m}$. In the line, the smallest diameter was found at $0.60 \mathrm{~m}$ distant from the plant until the depth range $0.10-0.20 \mathrm{~m}$.

\section{Conclusions}

Conilon coffee plants (Coffea canephora) genotype 02 under drip presented $74.5 \%$ and $64.5 \%$ 
Table 4. Characteristics of the coffee root system Conilon irrigated in a Red Yellow Latosol, sandy the clay texture, in two distances of the plant in the line (L) and two in the between, and at five distances on the between, in six depths.

\begin{tabular}{|c|c|c|c|c|c|c|}
\hline \multirow{3}{*}{$\begin{array}{l}\text { Distances of } \\
\text { the plant }(\mathrm{m})\end{array}$} & \multicolumn{6}{|c|}{ Depths (m) } \\
\hline & $0.00-0.10$ & $0.10-0.20$ & $0.20-0.30$ & $0.30-0.40$ & $0.40-0.50$ & $0.50-0.60$ \\
\hline & \multicolumn{6}{|c|}{ Volume $\left(\mathrm{mm}^{3}\right)$} \\
\hline $0.40 \mathrm{~L}$ & $356.93 \mathrm{dC}$ & $656.81 \mathrm{dA}$ & $463.58 \mathrm{cB}$ & $271.62 \mathrm{cD}$ & $163.02 \mathrm{dE}$ & $116.97 \mathrm{cF}$ \\
\hline $0.20 \mathrm{~L}$ & $852.97 \mathrm{cA}$ & $3452.56 \mathrm{aA}$ & $883.88 \mathrm{aB}$ & $651.44 \mathrm{aC}$ & $510.51 \mathrm{aD}$ & $240.48 \mathrm{aE}$ \\
\hline 0.20 & $2789.42 \mathrm{aA}$ & $723.82 \mathrm{cB}$ & $489.73 \mathrm{cC}$ & $279.71 \mathrm{cD}$ & $259.72 \mathrm{cD}$ & $177.37 \mathrm{bE}$ \\
\hline \multirow[t]{2}{*}{0.40} & $1126.74 \mathrm{bA}$ & $890.14 \mathrm{bB}$ & $674.70 \mathrm{bC}$ & $537.82 \mathrm{bD}$ & $473.92 \mathrm{bE}$ & $272.33 \mathrm{aF}$ \\
\hline & \multicolumn{6}{|c|}{ Surface area $\left(\mathrm{cm}^{2} \mathrm{dm}^{-3}\right)$} \\
\hline $0.40 \mathrm{~L}$ & $47.65 \mathrm{cC}$ & $96.95 \mathrm{aA}$ & $61.83 \mathrm{bB}$ & $10.63 \mathrm{dD}$ & $9.42 \mathrm{dD}$ & $7.76 \mathrm{dD}$ \\
\hline $0.20 \mathrm{~L}$ & $124.55 \mathrm{bA}$ & $48.46 \mathrm{bD}$ & $126.64 \mathrm{aA}$ & $76.24 \mathrm{aC}$ & $82.64 \mathrm{aB}$ & $39.13 \mathrm{aE}$ \\
\hline 0.20 & $40.81 \mathrm{~dB}$ & $44.59 \mathrm{cA}$ & $32.51 \mathrm{dC}$ & $30.07 \mathrm{cC}$ & $22.63 \mathrm{cD}$ & $21.13 \mathrm{cD}$ \\
\hline \multirow[t]{2}{*}{0.40} & $152.09 \mathrm{aA}$ & $50.40 \mathrm{bB}$ & $38.64 \mathrm{cC}$ & $41.73 \mathrm{bC}$ & $40.80 \mathrm{bC}$ & $33.68 \mathrm{bD}$ \\
\hline & \multicolumn{6}{|c|}{ Length $\left(\mathrm{m} \mathrm{dm}^{-3}\right)$} \\
\hline $0.40 \mathrm{~L}$ & $9.35 \mathrm{~dB}$ & $12.61 \mathrm{bA}$ & $5.99 \mathrm{bC}$ & $5.19 \mathrm{cD}$ & $2.27 \mathrm{cE}$ & $0.83 \mathrm{cF}$ \\
\hline $0.20 \mathrm{~L}$ & $20.42 \mathrm{bB}$ & $37.34 \mathrm{aA}$ & $5.93 \mathrm{bD}$ & $6.26 \mathrm{bC}$ & $6.54 \mathrm{aC}$ & $5.45 \mathrm{aD}$ \\
\hline 0.20 & $25.34 \mathrm{aA}$ & $8.10 \mathrm{~dB}$ & $7.79 \mathrm{aB}$ & $4.75 \mathrm{cC}$ & $3.47 \mathrm{bD}$ & $3.16 \mathrm{bD}$ \\
\hline \multirow[t]{2}{*}{0.40} & $15.07 \mathrm{cA}$ & $10.09 \mathrm{cB}$ & $7.90 \mathrm{aC}$ & $7.51 \mathrm{aC}$ & $6.55 \mathrm{aD}$ & $3.05 \mathrm{bE}$ \\
\hline & \multicolumn{6}{|c|}{ Diameter $(\mathrm{mm})$} \\
\hline $0.40 \mathrm{~L}$ & $0.688 \mathrm{aB}$ & $0.682 \mathrm{aB}$ & $0.684 \mathrm{aB}$ & $0.712 \mathrm{aA}$ & $0.710 \mathrm{aA}$ & $0.696 \mathrm{aB}$ \\
\hline $0.20 \mathrm{~L}$ & $0.662 \mathrm{bA}$ & $0.666 \mathrm{bA}$ & $0.640 \mathrm{cB}$ & $0.638 \mathrm{cB}$ & $0.646 \mathrm{cB}$ & $0.646 \mathrm{bB}$ \\
\hline 0.20 & $0.658 \mathrm{bB}$ & $0.654 \mathrm{bB}$ & $0.662 \mathrm{bB}$ & $0.676 \mathrm{bA}$ & $0.680 \mathrm{bA}$ & $0.676 \mathrm{aA}$ \\
\hline \multirow[t]{2}{*}{0.40} & $0.682 \mathrm{aA}$ & $0.622 \mathrm{cC}$ & $0.652 \mathrm{bB}$ & $0.666 \mathrm{bA}$ & $0.674 \mathrm{bA}$ & $0.684 \mathrm{aA}$ \\
\hline & \multicolumn{6}{|c|}{ Volume $\left(\mathrm{mm}^{3}\right)$} \\
\hline 0.60 & $968.75 \mathrm{aA}$ & $640.20 \mathrm{aB}$ & $608.09 \mathrm{aC}$ & $557.48 \mathrm{aD}$ & $387.22 \mathrm{aE}$ & $158.83 \mathrm{aF}$ \\
\hline 0.80 & $949.00 \mathrm{bA}$ & $644.49 \mathrm{aB}$ & $469.26 \mathrm{bC}$ & $257.41 \mathrm{bD}$ & $188.05 \mathrm{cE}$ & $151.66 \mathrm{bF}$ \\
\hline 1.0 & $849.43 \mathrm{cA}$ & $596.97 \mathrm{bB}$ & $225.75 \mathrm{eD}$ & $239.90 \mathrm{cC}$ & $213.16 \mathrm{bC}$ & $120.24 \mathrm{cF}$ \\
\hline 1.2 & $678.51 \mathrm{dA}$ & $431.07 \mathrm{cB}$ & 291.48 cC & $205.87 \mathrm{dD}$ & $182.88 \mathrm{cE}$ & $164.95 \mathrm{aF}$ \\
\hline 1.4 & $630.91 \mathrm{eA}$ & $428.94 \mathrm{cB}$ & $273.49 \mathrm{dC}$ & $158.83 \mathrm{eD}$ & $141.61 \mathrm{dE}$ & $125.89 \mathrm{cF}$ \\
\hline \multicolumn{7}{|c|}{ Surface area $\left(\mathrm{cm}^{2} \mathrm{dm}^{-3}\right)$} \\
\hline 0.60 & $148.26 \mathrm{aA}$ & $94.54 \mathrm{aB}$ & $78.88 \mathrm{aC}$ & $71.22 \mathrm{aD}$ & $43.24 \mathrm{aE}$ & $36.22 \mathrm{aF}$ \\
\hline 0.80 & $146.49 \mathrm{aA}$ & $55.25 \mathrm{cB}$ & $46.87 \mathrm{bC}$ & $23.99 \mathrm{bD}$ & $22.02 \mathrm{bD}$ & $21.83 \mathrm{bE}$ \\
\hline 1.0 & $91.36 \mathrm{bA}$ & $86.35 \mathrm{bB}$ & $26.59 \mathrm{cC}$ & $20.08 \mathrm{cD}$ & $18.80 \mathrm{cD}$ & $17.19 \mathrm{cE}$ \\
\hline 1.2 & $52.30 \mathrm{dA}$ & $19.51 \mathrm{eB}$ & $18.56 \mathrm{eB}$ & $16.67 \mathrm{dC}$ & $15.12 \mathrm{dC}$ & $14.75 \mathrm{dC}$ \\
\hline \multirow[t]{2}{*}{1.4} & $78.29 \mathrm{cA}$ & $24.07 \mathrm{~dB}$ & $20.69 \mathrm{dC}$ & $17.94 \mathrm{dD}$ & $17.40 \mathrm{cD}$ & $15.08 \mathrm{dE}$ \\
\hline & \multicolumn{6}{|c|}{ Length $\left(\mathrm{m} \mathrm{dm}^{-3}\right)$} \\
\hline 0.60 & $13.81 \mathrm{cA}$ & $5.94 \mathrm{bC}$ & $5.74 \mathrm{aC}$ & $12.55 \mathrm{aB}$ & $5.82 \mathrm{aC}$ & $3.54 \mathrm{aD}$ \\
\hline 0.80 & $13.96 \mathrm{cA}$ & $3.83 \mathrm{cB}$ & $3.68 \mathrm{eC}$ & $2.69 \mathrm{dC}$ & $2.63 \mathrm{dC}$ & $2.55 \mathrm{cC}$ \\
\hline 1.0 & $18.80 \mathrm{aA}$ & $9.83 \mathrm{aB}$ & $3.52 \mathrm{dC}$ & $3.44 \mathrm{cC}$ & $3.11 \mathrm{cD}$ & $3.07 \mathrm{bD}$ \\
\hline 1.2 & $17.85 \mathrm{bA}$ & $5.97 \mathrm{bB}$ & $5.20 \mathrm{bC}$ & $4.05 \mathrm{bD}$ & $3.61 \mathrm{bE}$ & $3.49 \mathrm{aE}$ \\
\hline \multirow[t]{2}{*}{1.4} & $3.86 \mathrm{dA}$ & $4.05 \mathrm{cA}$ & $3.82 \mathrm{cA}$ & $2.44 \mathrm{~dB}$ & $2.30 \mathrm{eB}$ & $2.20 \mathrm{~dB}$ \\
\hline & \multicolumn{6}{|c|}{ Diameter (mm) } \\
\hline 0.60 & $0.618 \mathrm{cC}$ & $0.650 \mathrm{cB}$ & $0.680 \mathrm{bA}$ & $0.650 \mathrm{cB}$ & $0.658 \mathrm{bB}$ & $0.664 \mathrm{bB}$ \\
\hline 0.80 & $0.686 \mathrm{aB}$ & $0.712 \mathrm{aA}$ & $0.664 \mathrm{bC}$ & $0.678 \mathrm{bB}$ & $0.662 \mathrm{bC}$ & $0.662 \mathrm{bC}$ \\
\hline 1.0 & $0.646 \mathrm{bB}$ & $0.666 \mathrm{cA}$ & $0.674 \mathrm{bA}$ & $0.632 \mathrm{~dB}$ & $0.658 \mathrm{bA}$ & $0.668 \mathrm{bA}$ \\
\hline 1.2 & $0.650 \mathrm{bC}$ & $0.690 \mathrm{bB}$ & $0.716 \mathrm{aA}$ & $0.714 \mathrm{aA}$ & $0.704 \mathrm{aA}$ & $0.708 \mathrm{aA}$ \\
\hline 1.4 & $0.604 \mathrm{cC}$ & $0.666 \mathrm{cA}$ & $0.622 \mathrm{cB}$ & $0.654 \mathrm{cA}$ & $0.624 \mathrm{cB}$ & $0.632 \mathrm{cB}$ \\
\hline
\end{tabular}

The averages followed by the same lowercase letter in the column and uppercase in the row do not differ statistically from one another. The Scott- Knott Test was applied at a 5\% probability level. 
(sandy to average texture) and $75.4 \%$ and $70.2 \%$ (sandy to clay texture) of the volume and root surface area, respectively, concentrated to the depth of $0.30 \mathrm{~m}$.

The root volume of coffee plant Conilon genotype 02 presented $70.5 \%$ up to $0,60 \mathrm{~m}$ of the plant's trunk.
The root surface area was $69.0 \%$ (sandy to medium texture) and $66.4 \%$ (sandy to clay texture) up to $0.60 \mathrm{~m}$ from the plant's trunk.

The largest root length was found in the soil surface depth range, decreasing in-depth, same behavior for the diameter.

\section{Literature Cited}

Amaral, J.F.T.; Martinez, H.E.P.; Laviola, B.G.; Fernandes Filho, E.I.; Cruz, C.D.

2011. Eficiência de utilização de nutrientes por cultivares de cafeeiro. Ciência Rural, 41(4): 621-629.

Barreto, C.V.G.; Sakai, E.; Arruda, F.B.; Silva, E.A.; Pires, R.C.M. 2006. Distribuição espacial do sistema radicular do cafeeiro fertirrigado por gotejamento em Campinas. Bragantia, 65(4): 641-647.

Belan, L.L.; Silva, K.G.; Tomaz, M.A.; Jesus Junior, W.C.; Amaral, J.A.T.; Amaral, J.F.T.

2011. Aspectos fisiológicos do cafeeiro Conilon: uma abordagem sistemática. Nucleus, 8(1): 225-240.

Bonomo, D.Z.; Bonomo, R.; Pezzopane, J.R.M.; Souza, J.M. 2014. Alternativas de manejo de água de irrigação em cultivos de Conilon. Coffee Science, 9(4):537-545.

Cassidy, D.M.S.; Kumar, D.

1984. Root distribution of Coffea arabica L. in Zimbabwe. I. The effect of plant density, mulch, cova planting and shade in Chipinge. Zimbabwe Journal of Agricultural Research, 22(2): 119-132.

Comas, L.H.; Becker, S.R.; Cruz, V.M.V.; Byme, P.F.; Dierig, D.A. 2013. Root traits contributing to plant productivity under drough. Frontiers in Plant Science, 4(1): 1-16.

CONAB-Companhia Nacional de Abastecimento. 2017. Acompanhamento da safra brasileira: Café. CONAB. Brasilia, Brazil. 98 p.

Embrapa - Empresa Brasileira de Pesquisa Agropecuária. 2013. Centro Nacional de Pesquisa de Solos. Sistema Brasileiro de Classificação de Solos. $3^{\mathrm{a}}$ ed. Embrapa. Brasilia, Brazil. 353 p.

Embrapa - Empresa Brasileira de Pesquisa Agropecuária. 2011. Centro Nacional de Pesquisa de Solos. Manual de métodos de análise de solo. 2. ed. Rio de Janeiro, Brazil. 225 p.

Imada, S.; Yamanaka, N.; Tamai, S.

2008. Water table depth effects Populus alba fine root growth and whole plant biomass. Functional Ecology, 22(6): 1018-1026.

Jorge, L.A.C.; Silva, D.J.C.B.; Rodrigues, A.F.O.

2010. SAFIRA - Software para a análise de fibras e raízes. Versão 1.1. São Carlos: Embrapa Instrumentação Agropecuária, 54 p.

Marschner, $\mathrm{H}$.

2011. Mineral nutrition of higher plants. 3.ed. San Diego: Academic Press, 684 p.
Martins, L.D.; Machado, L.S.; Tomaz, M.A.; Amaral, J.F.T. 2015. The nutritional efficiency of Coffea spp. A review. African Journal of Biotechnology, 14(9): 728-734.

Mota, A.C.V.; Nick, J.A.; Yorinori, G.T.; Serrat, B.M.

2006. Distribuição horizontal e vertical da fertilidade do solo e das raízes de cafeeiro (Coffea arabica L.) cultivar Catuaí. Acta Scientiarum Agronomy, 28(4): 455-463.

Partelli, F.L.; Covre, A.M.; Oliveira, M.G.; Alexandre, R.S.; Vitória, E.L.; Silva, M.B.

2014. Root system distribution and yield of 'Conilon' coffee propagated by seeds or cuttings. Pesquisa Agropecuária Brasileira, 49(5): 349-355.

Partelli, F.L.; Vieira, H.D.; Santiago, A.R.; Barroso, D.G. 2006. Produção e desenvolvimento radicular de plantas de café 'Conilon' propagadas por sementes e por estacas. Pesquisa Agropecuária Brasileira, 41(6): 949-954.

Rena, A.B.; DaMatta, F.M.

2002. O sistema radicular do cafeeiro: estrutura e ecofisiologia. In: Zambolin, L. (Ed.). O estado da arte de tecnologias na produção de café. Viçosa: UFV, p. 11-92.

Rena, A.B.; Guimarães, P.T.G.

2000. Sistema radicular do cafeeiro: estrutura, distribuição, atividades fatores que o influenciam. Belo Horizonte: Empresa de Pesquisa Agropecuária de Minas Gerais. Belo Horizonte, Brazil. 80 p.

Rodrigues, L.A.; Martinez, H.E.P.; Neves, J.C.L.; Novais, R.F.;

Mendonça, S.M.

2001. Growth response of coffee tree shoots and roots to subsurface liming. Plant and Soil, 234(2): 207-214.

Ronchi, C.P.; Sousa Júnior, J.M.; Almeida, W.L.; Souza, D.S.; Silva, N.O.; Oliveira, L.B.; Guerra, A.M.N.M.; Ferreira, P.A. 2015. Morfologia radicular de cultivares de café arábica submetidas a diferentes arranjos espaciais. Pesquisa Agropecuária Brasileira, 50(3): 187-195.

Silva, L.M.; Crusciol, C.A.C.; Cruciol, J.H.; Viegas, P.R.A.; Pedrotti, A.

2013. Comprimento radicular e nutrição de cultivares de painço em resposta à calagem. Científica, 41(1): 64-72.

Silva, A.L.; Bruno, I.B.; Reichardt, K.; Bacchi, O.O.S.; Dourado

Neto, D.; Favarin, J.L.; Costa, F.M.P.; Timm, L.C.

2009. Soil water extraction by roots and $\mathrm{Kc}$ for the coffee crop. Revista Brasileira de Engenharia Agrícola e Ambiental, 13(3): 257-261. 